\title{
A CONTRIBUIÇÃO SINDICAL OBRIGATÓRIA DO SERVIDOR PÚBLICO ESTATUTÁRIO SOB A PERSPECTIVA DA LEGALIDADE TRIBUTÁRIA.
}

\author{
THE MANDATORY TRADE UNION CONTRIBUTION OF THE STATUTORY \\ PUBLIC SERVER UNDER THE PERSPECTIVE OF TAX LEGALITY
}

\author{
Daniela Ramos de Oliveira dos Santos ${ }^{1}$ \\ Antônio Carlos Diniz Murta ${ }^{2}$
}

\section{RESUMO}

O artigo propõe a discussão da legalidade tributária em face daIN $n^{\circ}$ 01/2008 do MTE que estendeu a contribuição sindical obrigatória do art. 149 da CF/88 e dos art. 578 a 591 da CLT para os servidores públicos estatutários. Aborda-se a origem e a natureza compulsória da contribuição sindical, sob a legalidade tributária do art. 150, I, da CF/88 e a vedação da analogia no Direito Tributário quando trata de exigência de tributo principal (art. $108, \S 1^{\circ}$ do CTN). Parte-se da hipótese que a IN 01/2008 do MTE é ilegal, já que a obrigação tributária principal decorre de lei.

Palavras-chave: Contribuição Sindical. Obrigatoriedade. Servidor Público. Legalidade Tributária

\begin{abstract}
The article proposes the discussion of tax legality in the face of IN No 01/2008 of the MTE which extended compulsory union dues of art. 149 of CF / 88 and art. 578-591 of the Labor Code for statutory civil servants. It discusses the origin and nature of compulsory union dues under the tax legality of art. 150, I, CF / 88 and the seal of the analogy in Tax Law when dealing with major tax requirement (art. 108, $\S 1$ of CTN ). It started from the hypothesis that the IN 01/2008 MTE is illegal, since the main tax obligation arises from law.
\end{abstract}

Keywords: Uion Fees. Mandatory. Public Server. Legality Tax

\footnotetext{
${ }^{1}$ Mestranda em Direito Público pela Fundação Municipal para Educação Comunitária - FUMEC, Minas Gerais (Brasil).

${ }^{2}$ Doutorado em Direito pela Universidade Federal de Minas Gerais (UFMG), Minas Gerais (Brasil). Professor Titular de Direito Tributário da Universidade FUMEC, Minas Gerais (Brasil).E-mail:acmurta@ fumec.br
} 


\section{INTRODUÇÃO}

O Sindicalismo no Brasil se deu a partir da Era de Getúlio Vargas, em 1930, quando restou estabelecida a criação de direitos mínimos dos trabalhadores e a instituição de entidades representativas das categorias profissionais e econômicas. Assim, os sindicatos surgiram com o objetivo de atuar na defesa dos direitos dos trabalhadores sem qualquer finalidade lucrativa. À época, que surgiram, os sindicatosnão possuíam recursos para custearem as suas despesas e funcionamento.

Desse modo, surge a contribuição sindical na Constituição de 1937, prevista no artigo 138, que conferiu às entidades sindicais o direito de impor contribuições, bem como exercer funções delegadas no Poder Público. Esse dispositivo foi regulamentado pelo Decreto-Lei $n^{\circ} 1.402$ de 1939, que incluiu, além das prerrogativas das entidades sindicais, a imposição de contribuições para aqueles que participassem das profissões ou categorias representadas.

Em 1940, o Decreto-Lei no 2.377 conceituou a contribuição como "imposto sindical" e, estabeleceu à época, o recolhimento pelas empresas, bem como indicou o valor de percentual a ser distribuído pelos sindicatos às entidades de grau superior e ao Ministério do Trabalho e do Emprego.

A Consolidação das Leis e do Trabalho manteve a previsão da contribuição sindical obrigatória nos artigos 578 a 610. Ela corresponde ao desconto anual de 1 (um) dia de salário nos vencimentos dos trabalhadores com o devido repasse na forma do disposto do artigo 589 da Consolidação das Leis Trabalhistas

A CF/88 preservou a contribuição sindical obrigatória, mantendo-a como a principal fonte de custeio para a manutenção das atividades dos sindicatos através do artigo $8^{\circ}$, inciso IV e artigo 139.

As contribuições sindicais são conhecidas como contribuições especiais (artigo 149 da $\mathrm{CF} / 88$ ) e possui todas as suas características presentes no artigo $3^{\circ}$ do Código Tributário Nacional. 
A contribuição tornou-se obrigatória dos servidores e empregados públicos, após a Instrução Normativa $n^{\circ} 01$ do Ministério do Trabalho e do Emprego, expedida em 30 de Setembro de 2008.

Todavia, a discussão diz respeito a extensão do recolhimento do pagamento da contribuição sindical obrigatória por meio de Instrução Normativa editada pelo Ministério do Trabalho e do Emprego apenas aos servidores públicos estatutários, já que os empregados públicos, apesar de exercerem função pública, estão adstritos às regras da CLT.

A contribuição sindical obrigatória é dotada de natureza tributária, sendo que a sua fixação tem que se dar por intermédio de lei, em apreço ao princípio da legalidade tributária cuja previsão está contida no artigo 150, inciso I da CF/88. Ademais, há de se considerar o princípio da legalidade em sentido estrito (artigo $5^{\circ}$, II, CR/88), bem como a vedação da interpretação por analogia (art. $108, \S 1^{\circ}, \mathrm{CTN}$ ) no direito tributário, no caso de obrigação tributária principal.

\section{HISTÓRICO DA CONTRIBUIÇÃO SINDICAL OBRIGATÓRIA NO BRASIL}

Em 1930, na época de Getúlio Vargas, iniciou-se uma era de grandes movimentos revolucionários no que diz respeito aos direitos dos trabalhadores, culminando em grandes modificações sociais e políticas no país. Ainda, foi nessa época que se deu início ao fortalecimento do movimento sindical brasileiro.

Nessa perspectiva, os sindicatos surgiram no século XIX com o objetivo de representar e defender os interesses dos trabalhadores das categorias profissionais e/ou econômicas. Tais entidades não possuem finalidade lucrativa e, portanto, não possuem fontes primárias de arrecadação para custearem suas despesas e seu funcionamento.

Importante destacar que nessa fase, nasce um modelo de sindicalismo "corporativista" em virtude da grande influência das corporações de ofício já existentes à época em outros países como Itália, Portugal e Espanha. Desse modo, sob forte influência da visão corporativista, os sindicatos exerciam funções delegadas pelo poder público, com a tutela sendo resguardada pelo Ministério do Trabalho e do Emprego.

Posteriormente, cria-se o Decreto-Lei no 19.770 de 1931, como uma das garantias ao movimento sindical, que regulou a sindicalização das classes patronais e operárias no Brasil. 
Com a promulgação da Constituição da República dos Estados Unidos do Brasil em 1934, foi conferida a garantia de novos direitos trabalhistas, bem como a pluralidade e a autonomia sindical, rompendo com o modelo de organização prevista no Decreto-Lei $n^{\circ}$ 19.770 de 1931.

A contribuição sindical surge com a nova Constituição em 1937, noartigo 138, que foi definida equivocadamente como "imposto sindical", já que o referido tributo sempre foi uma espécie de contribuição e não de imposto, como será demonstrado. Adiante, a regulamentação se deu pelo art. $3^{\circ}$ do Decreto-Lei $\mathrm{n}^{\circ} 1.402$ de 1939que incluiu, além das prerrogativas das entidades sindicais, a imposição de contribuições para aqueles que participarem das profissões ou categorias representadas.

Com o Decreto Lei $\mathrm{n}^{\mathrm{o}} 2.377$ de 1940, os sindicatos passaram a ter a receita da contribuição, denominada "Imposto Sindical". Esse decreto regulamentou a contribuição determinando o seu pagamento apenas uma vez ao ano e equivalente a um dia de trabalho para os empregados, a ser descontado todo mês de março e, para os empregadores, numa importância fixa, proporcional ao capital social registrado, conforme tabela variável. O seu recolhimento passou a ser feito pelas empresas, além de indicar o valor de percentual a ser distribuído pelos sindicatos às entidades de grau superior e ao Ministério do Trabalho e do Emprego.

Seguiu-se o Decreto-Lei no 4.298, de 1942, que regulou o recolhimento do imposto, sua aplicação e fiscalização com a instituição da Comissão do imposto Sindical e o fundo Social Sindical.

A Consolidação das Leis do Trabalho (Decreto-Lei n ${ }^{\circ}$ 5.452, de 01 de maio de 1943) tratou de reunir sistematicamente as disposições atinentes ao Imposto Sindical destinando o capítulo III para tratar sobre as questões sindicais, que engloba os artigos 578 a 610 .

Sobre o recolhimento da contribuição sindical, Maurício Godinho Delgado (2009) explica:

Trata-se de receita recolhida uma única vez, anualmente, em favor do sistema sindical, nos meses e montantes fixados na CLT, quer se trate de empregado, profissional liberal ou empregador (arts. 580 e seguintes). Ilustrativamente, no caso de empregado, este sofrerá o respectivo desconto, na folha de pagamento do mês de março, à base do salário equivalente a um dia de labor. (DELGADO, 2009, p. 12321233)

A Constituição de 1946 recepcionou as regras da CLT concernentes ao imposto sindical, já que não houve qualquer vedação. A Lei n 4.140 de 1962 alterou os percentuais e 
a forma de cálculo do imposto sindical devido pelos trabalhadores autônomos, profissionais liberais e empregadores. Em 1963, a Lei nº 4.214, de 1963 (Estatuto do Trabalhador Rural), em seu art. 135, estendeu a exigência do imposto para os trabalhadores rurais, sendo que a lei foi revogada posteriormente pela Lei $\mathrm{n}^{\circ} 5.889$, de 1973.

Posteriormente, a nomenclatura do Imposto Sindical foi alterada para contribuição sindical através do Decreto-Lei nº 27, de 1966. O Decreto Lei nº 229 de 1967 alterou a CLT quanto à atualização da nomenclatura contribuição sindical.

O artigo 159, §1, da Constituição de 1967 manteve a exigência da contribuição sindical, apesar da necessidade de regulamentação para que os sindicatos pudessem arrecadálas.

A CF/88 preservou a contribuição sindical obrigatória, mantendo-a como a principal fonte de custeio para a manutenção das atividades dos sindicatos. Atualmente, existem três modalidades de contribuições sindicais, são elas:

a) a contribuição confederativa que é fixada pela assembleia para o custeio do sistema confederativo do respectivo sindicato, de natureza voluntária e não tributária, sendo somente devida para os empregados filiados, conforme Súmula $\mathrm{n}^{\circ} 666$ que foi convertida em Súmula Vinculante $n^{\circ} 40^{3}$ pelo STF (Supremo Tribunal Federal) e Precedente Normativo $n^{\circ}$ $119^{4}$ do TST (Tribunal Superior do Trabalho). Está prevista no artigo $8^{\circ}$, inciso IV, parte inicial da $\mathrm{CF} / 88$.

b) contribuição sindical fixada em lei, que é descontada compulsoriamente de todos os trabalhadores que participem de uma determinada categoria econômica ou profissional, em favor do sindicato representativo da mesma categoria ou profissão. Possui natureza tributária, pois atende todos os elementos constantes do art. $3^{\circ}$ do CTN (Código Tributário Nacional), além de trazer previsão no artigo $8^{\circ}$, inciso IV, parte final e artigo 149, ambos, da CF/88.

c) contribuição assistencial prevista no artigo 548, alínea "b”, da CLT (Consolidação das Leis Trabalhistas), que está prevista em convenção, acordo, sentença normativa de

\footnotetext{
${ }^{3}$ Súmula STF no 404. A contribuição confederativa de que trata o art. $8^{\circ}$, IV, da Constituição Federal, só é exigível dos filiados ao sindicato respectivo.

${ }^{4}$ PRECEDENTE TST No 119 CONTRIBUIÇÕES SINDICAIS - INOBSERVÂNCIA DE PRECEITOS CONSTITUCIONAIS - $\quad$ (mantido) - $\quad$ DEJT divulgado em 25.08 .2014 "A Constituição da República, em seus arts. $5^{\circ}, \mathrm{XX}$ e $8^{\circ}, \mathrm{V}$, assegura o direito de livre associação e sindicalização. É ofensiva a essa modalidade de liberdade cláusula constante de acordo, convenção coletiva ou sentença normativa estabelecendo contribuição em favor de entidade sindical a título de taxa para custeio do sistema confederativo, assistencial, revigoramento ou fortalecimento sindical e outras da mesma espécie, obrigando trabalhadores não sindicalizados. Sendo nulas as estipulações que inobservem tal restrição, tornam-se passíveis de devolução os valores irregularmente descontados." Histórico: nova redação dada pela SDC em sessão de 02.06.1998 - homologação Res. 82/1998, DJ 20.08.1998.
} 
dissídio e somente devida para aqueles que forem filiados ou associados de entidade sindical.

A contribuição sindical obrigatória, que é o objeto de discussão, não se confunde com a contribuição confederativa e, tão menos, com a contribuição assistencial.

Ainda, os sindicatos possuem a prerrogativa de estipularem outras contribuições dos seus filiados que é conhecida como a contribuição associativa. Ela está prevista no artigo 513, alínea 'e', da CLT, que se funda no estatuto ou ata de assembleia geral de cada entidade. Esta contribuição associativa é voluntária, sendo, portanto, paga apenas para os associados à entidade sindical.

Porém, o desconto da contribuição sindical foi estendido para todos os servidores públicos estatutário e empregado públicos das três esferas da Administração direta e indireta (federal, estadual e municipal) através da Instrução Normativa $n^{\circ}$ 01/2008 do Ministério do Trabalho e Emprego em 30 de setembro de 2008.

\section{A NATUREZA JURÍDICA DA CONTRIBUIÇÃO SINDICAL OBRIGATÓRIA}

As contribuições sindicais, também denominadas como contribuições especiais, estão previstas no artigo 149da CF/88 que subdivide as contribuições especiais em: contribuições sociais, contribuições de intervenção no domínio econômico e contribuições das categorias profissionais ou econômicas.

Ademais, todas as características presentes no artigo $3^{\circ}$, do $\mathrm{CTN}$, que define o conceito de tributo, estão inseridas nas contribuições especiais do artigo 149 da CF/88.

Hugo de Brito Machado (2001), comentando sobre o contigo no artigo 149 da Constituição Federal, assim define:

Contribuição social é como uma espécie de tributo com finalidade constitucionalmente definida, a saber, intervenção no domínio econômico, interesse de categoria profissional ou econômica e seguridade social. (MACHADO, 2001, p. 428)

Por este motivo, o referido tributo é considerado, nos dizeres de Luciana Batista Santos (2011) como um "tributo finalístico", já que o mesmo possui uma finalidade e uma destinação específica, qual seja: custear a atividade sindical, sendo queparte dela é repassada 
ao Estado. A repartição do montante é dirigida às entidades que compõem o sistema confederativo nos percentuais indicados pelo art. 589 da CLT.

Além de ser um tributo finalístico, a contribuição sindical possui a função parafiscal, que é uma característica inerente a esta espécie de contribuição, posto que a sua destinação é para o órgão que não pertence à Administração do Estado, mas que prestam serviços de natureza não essencial através dessa receita.

No que se refere à função parafiscalexistente nas contribuições especiais, dentre elas, a contribuição sindical, Luciana Batista Santos (2011) tem o seguinte entendimento:

\begin{abstract}
(...) o fato de serem tributos parafiscais, significando que a competência tributária (poder legislar sobre o tributo) é exercida por um ente da Federação, mas que a lei transfere a outra pessoa jurídica a capacidade ativa, ou seja, o poder para arrecadar, fiscalizar e executar leis, serviços, atos ou decisões administrativas em matéria tributária, consoante permitido no art.7 do Código Tributário Nacional. (SANTOS, 2011, pag. 36).
\end{abstract}

Neste sentido, percebe-se que a pessoa jurídica de direito público que arrecada é diversa da pessoa jurídica de direito público que institui o tributo. Ou seja, o ente que recebeu a capacidade ativa para poder arrecadar e fiscalizar poderá também, usufruir dos valores arrecadados para o seu benefício, como se pode visualizar nas contribuições sindicais.

Logo, por ser considerada uma espécie de tributo com natureza finalista e parafiscal, a contribuição sindical detém a característica da compulsoriedade, de maneira que, se torna obrigatória para todos os trabalhadores integrantes de determinada categoria, independentemente de serem sindicalizados ou não.

Verifica-se que não há dúvidas de que a natureza jurídica da contribuição sindical é tributária, já que obriga a todos os integrantes da categoria econômica e profissional, cujo respaldo está contido nos artigos $8^{\circ}$, inciso IV, "parte final", combinado com o artigo 149, ambos, da CF/88.Assim, todos os trabalhadores devem arcar com o pagamento do montante equivalente à importância de um dia de trabalho, de acordo com o artigo 580, inciso I da CLT.

O recolhimento da referida contribuição é feita pelo empregador que desconta o tributo dos seus empregados. Por se tratar de um tributo federal, a União, ao instituir a contribuição sindical, destina a arrecadação deste tributo para os sindicatos representantes das categorias profissionais. Dessa maneira, caberão aos sindicatos as funções de arrecadar e fiscalizar as contribuições sindicais, em razão da parafiscalidade existente nesta espécie de tributo. 


\section{A LEGALIDADE TRIBUTÁRIA NA CF/88(ART. 150, I, CF/88) E A INSTRUÇÃO NORMATIVA Nº1/2008 DO MTE.}

Diante da natureza jurídica tributária da contribuição sindical, considera-se que está adstrita as regras gerais do Direito Tributário e possui relação com os demais tributos da mesma categoria. $\mathrm{O}$ artigo 150 , inciso $\mathrm{I}$, da $\mathrm{CF} / 88$ determina que a obrigação tributária decorre da incidência de determinada norma legal sobre o caso concreto, de modo que impeça a atuação discricionária e fora dos ditames legais do Estado. Portanto, a partir da aplicação do princípio da legalidade, não é permitida a exigência de um tributo sem lei que o estabeleça.

A aplicabilidade dos artigos 578 e seguintes do CLT aos servidores públicos estatutários como sujeito passivo da contribuição sindical, parte da premissa de que o conteúdo da norma é amplo e genérico, alcançando todos aqueles que "participem das categorias econômicas ou profissionais ou das profissões liberais".

À luz desse raciocínio, o STF entende majoritariamente (AI 456634 ${ }^{5}$, ARE 723891616) que a contribuição sindical prevista nos artigos 578 e seguintes do CTN foi recepcionada pelo art. $8^{\circ}$, inciso IV, parte final da $\mathrm{CF} / 88$, tornando-se desnecessária a edição de lei formal específica.

Em que pese a relativa pacificação jurisprudencial e da orientação seguida pelo MTE através da Instrução Normativa $n^{\circ}$ 01/2008 nesse caso, a redação contida nos artigos 578 e

${ }^{5}$ EMENTA: CONSTITUCIONAL. CONTRIBUIÇÃO SINDICAL. SERVIDORES PÚBLICOS. Art. $8^{\circ}$, IV, da Constituição Federal. I. - A contribuição sindical instituída pelo art. $8^{\circ}$, IV, da Constituição Federal constitui norma dotada de auto-aplicabilidade, não dependendo, para ser cobrada, de lei integrativa. II. - Compete aos sindicatos de servidores públicos a cobrança da contribuição legal, independentemente de lei regulamentadora específica. III. - Agravo não provido. (SUPREMO TRIBUNAL FEDERAL, AI 456634 AgR, Relator(a): Min. CARLOS VELLOSO, Segunda Turma, julgado em 13/12/2005, DJ 24-02-2006).

${ }^{6}$ EMENTA. Embargos de declaração em recurso extraordinário com agravo. 2. Decisão monocrática. Embargos de declaração recebidos como agravo regimental. 3. Direito Tributário. 4.Contribuição sindical. Norma autoaplicável. Precedentes. 5. Alegação de ausência de fundamentação. Não cabe ao STF rever decisão que, na origem, aplica o disposto no art. 543-B do CPC. 6. Agravo regimental a que se nega provimento. (SUPREMO TRIBUNAL FEDERAL, ARE 723891, Relator Min. Gilmar Mendes, Segunda Turma, julgado em 04/08/15, DJ 24-08-2015) 
579 da CLT, não elenca expressamente os servidores públicos estatutários enquanto sujeitos passivos da contribuição.

Como se observa, a redação dos dispositivos acima não define expressamente a inclusão dos servidores públicos dentre o rol que a norma estabelece. Ademais, não podemos considerar os cargos ocupados pelos servidores públicos estatutários como profissões liberais, conforme determina o artigo 578 da CLT. E, ainda, importante pontuar que o conceito de categoria econômica ou profissional não se enquadra à natureza do trabalho exercido pelos servidores públicos estatutários enquanto ocupantes de cargos públicos.

Perceptível é, que a CLT jamais incluiu o servidor público estatutário dentre os empregados que foram alcançados pela contribuição sindical, posto que o direito de sindicalização dos servidores públicos, de maneira geral,se deu somente a partir da CF/88, que é posterior a CLT.

De acordo com a CLT, o empregado é aquele trabalhador que possui vínculo jurídico de natureza contratual, não se confundindo com o servidor público estatutário, cujo cargo é público e regido por lei específica. O artigo 580 da CLT, nos seus incisos I e II, de forma clara,elenca os sujeitos passivos da contribuição sindical, que são: empregados, agentes ou trabalhadores autônomos e profissionais liberais.

Convém destacar a posição de Eduardo Sabbag (2014):

\footnotetext{
A contribuição sindical obrigatória possui inafastável feição tributária e, sujeitandose as normas gerais de direito tributário, torna-se obrigatória à todos trabalhadores celetistas, integrantes da categoria, sindicalizados ou não. Naturalmente, não se estende àqueles vinculados a regimes próprios de previdência, como os servidores públicos. (SABBAG, 2014, p. 525)
}

Do mesmo modo, os artigos 583, 584 e 585 da CLT em momento algum, definem a obrigação tributária para os servidores públicos sob o regime estatutário.

Por essas considerações, a CLT não considerou servidor público estatuário como sujeito passivo da obrigação tributária, no que diz respeito à contribuição sindical obrigatória, por motivos óbvios: a CLT rege as relações de trabalho de natureza privada, ao passo que, o servidor público estatutário é regido por lei especifica editada pela Administração Pública ao qual ele é vinculado.

Assim, como na CLT, o artigo 97, inciso III, do CTN que regulamenta o artigo 146, inciso III, alínea 'a' da $\mathrm{CF} / 88$, estabelece que somente a lei é que define o fato gerador da obrigação principal e o seu sujeito. Assim, como a CLT foi recepcionada pela CF/88 como lei 
ordinária federal, ela instituiu a contribuição sindical, bem como o seu pagamento, recolhimento e definição do sujeito passivo, que está expresso no seu artigo 578.

Nesse contexto, é inadmissível que um ato normativo do Ministério do Emprego e Trabalho determine quem é o sujeito da obrigação tributária da contribuição sindical. Por conseguinte, pode-se afirmar que o ato normativo padece eivado de ilegalidade.

A extensão da contribuição sindical prevista na CLT para os servidores públicos estatutários é fruto de uma construção jurisprudencial do STF (Supremo Tribunal Federal) que se consolidou na prática por intermédio da Instrução Normativa $n^{\circ}$ 01/2008 do Ministério do Trabalho e Emprego. Não há nenhuma lei, no sentido estrito, que defina o servidor público estatutário como sujeito passivo da obrigação tributária. Nesse sentido, destacamos a opinião de Carvalho (2009):

Por fim, mera "necessidade de uniformizar o procedimento de recolhimento da contribuição sindical (...) pela administração pública federal, estadual e municipal" e a existência de alguns precedentes judiciais sem efeitos vinculantes e erga omnes não legitimam a cobrança compulsória do tributo “ de todos os servidores e empregados públicos" do país com base em uma instrução normativa , o que viola, pelas razões já expostas, o princípio da legalidade tributária (art. 150, I, da CF/88) (CARVALHO, 2009, p. 02)

Ademais, os antecedentes jurisprudenciais do Supremo Tribunal Federal e Superior Tribunal de Justiça que ensejaram a edição da Instrução Normativa $n^{\circ}$ 01/2008 do MTE, com a devida vênia, não se prestam a justificar o ato normativo. No RE $n^{\circ} 180.745^{7}$ do STF, a fundamentação é que os artigos 578 e seguintes da CLT foram recepcionados pelo artigo $8^{\circ}$, inciso IV da $\mathrm{CF} / 88$ e que contribuição sindical obrigatória não fere o princípio da liberdade e autonomia sindical. Entretanto, na decisão não há qualquer entendimento de que os servidores públicos estatuários são sujeitos passivos dessa obrigação tributária. O RE no $146.733 / \mathrm{SP}^{8}$ não

${ }^{7}$ EMENTA: Sindicato: contribuição sindical da categoria: recepção. A recepção pela ordem constitucional vigente da contribuição sindical compulsória, prevista no art. 578 CLT e exigível de todos os integrantes da categoria, independentemente de sua filiação ao sindicato resulta do art. $8^{\circ}$, IV, in fine, da Constituição; não obsta à recepção a proclamação, no caput do art. $8^{\circ}$, do princípio da liberdade sindical, que há de ser compreendido a partir dos termos em que a Lei Fundamental a positivou, nos quais a unicidade (art. $8^{\circ}$, II) e a própria contribuição sindical de natureza tributária (art. $8^{\circ}, \mathrm{IV}$ ) - marcas características do modelo corporativista resistente -, dão a medida da sua relatividade (cf. MI 144, Pertence, RTJ 147/868, 874); nem impede a recepção questionada a falta da lei complementar prevista no art. 146, III, CF, à qual alude o art. 149, à vista do disposto no art. 34, $\S \S 3^{\circ}$ e $4^{\circ}$, das Disposições Transitórias(cf. RE 146733, Moreira Alves, RTJ 146/684, 694) (SUPREMO TRIBUNAL FEDERAL, RE 180.745, Relator Ministro Sepúlveda Pertence, $1^{\mathrm{a}}$ Turma, Publicado no DJ 08/05/1998). 
guarda nenhuma pertinência quanto à exigibilidade da contribuição sindical dos servidores públicos estatutários.

Apenas nos julgados do STJ (RESP $612.842^{9}$ e RESP 442.509/SP(0) é que as decisões judiciais reconhecem a obrigação da Administração Pública quanto ao recolhimento da contribuição sindical dos seus servidores públicos que são regidos por norma estatutária própria. Desse modo, os Tribunais Superiores ao entenderem pela auto- aplicabilidade do artigo $8^{\circ}$, inciso IV, parte final da $\mathrm{CF} / 88$ para os servidores públicos estatutários contrariam o inciso I, do artigo 150 da CF/88.

Causa-nos enorme estranheza o entendimento do Poder Judiciário quanto o recolhimento da contribuição sindical do servidor público estatutário, já que não trata de categoria profissional e, sequer, possui relação de trabalho contratual, como é o caso dos empregados celetistas. Ademais, nem por interpretação analógica, o tratamento conferido aos

${ }^{8}$ EMENTA: contribuição social sobre o lucro das pessoas jurídicas. lei 7689/88. - não e inconstitucional a instituição da contribuição social sobre o lucro das pessoas jurídicas, cuja natureza e tributária. Constitucionalidade dos artigos 1., 2. e 3. da lei 7689/88. Refutação dos diferentes argumentos com que se pretende sustentar a inconstitucionalidade desses dispositivos legais. - ao determinar, porém, o artigo 8. da lei 7689/88 que a contribuição em causa já seria devida a partir do lucro apurado no período-base a ser encerrado em 31 de dezembro de 1988, violou ele o princípio da irretroatividade contido no artigo 150, iii, "a", da constituição federal, que proíbe que a lei que institui tributo tenha, como fato gerador deste, fato ocorrido antes do início da vigência dela. Recurso extraordinário conhecido com base na letra "b" do inciso iii do artigo 102 da constituição federal, mas a que se nega provimento porque o mandado de segurança foi concedido para impedir a cobrança das parcelas da contribuição social cujo fato gerador seria o lucro apurado no período-base que se encerrou em 31 de dezembro de 1988. Declaração de inconstitucionalidade do artigo 8. da lei 7689/88." (SUPREMO TRIBUNAL FEDERAL, RE 146.733/SP, Relator Moreira Alves, Tribunal Pleno, Publicado no DJ 06/11/1992)

${ }^{9}$ EMENTA: ADMINISTRATIVO - RECURSO ESPECIAL - DECADÊNCIA - INOCORRÊNCIA CONTRIBUIÇÃO SINDICAL ("IMPOSTO SINDICAL") - SERVIDOR PÚBLICO MUNICIPAL RECOLHIMENTO COMPULSÓRIO. 1. Não se configura a decadência se o writ foi impetrado antes de escoado o prazo de cento e vinte dias da efetiva lesão de direito líquido e certo do impetrante. 192 . A lei específica que disciplina a contribuição sindical compulsória ("imposto sindical") é a CLT, nos arts. 578 e seguintes, a qual é aplicável a todos os trabalhadores de determinada categoria, inclusive aos servidores públicos, observada a unicidade sindical e a desnecessidade de filiação, segundo a jurisprudência do Supremo Tribunal Federal, que considerou recepcionada a exação pela atual Constituição Federal. 3. É obrigatório o recolhimento do "imposto sindical" pela Administração Pública Municipal a pedido de qualquer das entidades incluídas no rol dos beneficiários da importância da arrecadação, como previsto no art. 589 da CLT. 4. Recurso especial improvido. (SUPERIOR TRIBUNAL DE JUSTIÇA, RESP 612.842, $2^{\mathrm{a}}$ Turma, Relatora Eliana Calmon, Publicado no DJ $11 / 04 / 2005)$

${ }^{10}$ EMENTA: PROCESSUAL CIVIL. RECURSO ESPECIAL. CONTRIBUIÇÃO SINDICAL. SERVIDOR PÚBLICO MUNICIPAL. COBRANÇA DEVIDA. PRECEDENTES 1. "A partir de promulgação da Emenda Constitucional 45/2004, a competência para processar e julgar ações em que se questiona a cobrança da contribuição sindical (...) é da Justiça do Trabalho, salvo se já houver sido proferida sentença na Justiça Comum, quando então prevalecerá a competência recursal do tribunal respectivo" (CC n. 57.915-MS, Primeira Seção, relator Ministro Teori Albino Zavascki, DJ de 27.3.2006). 2. O Superior Tribunal de Justiça, em consonância com a jurisprudência firmada no Supremo Tribunal Federal, consolidou o entendimento de que a contribuição sindical, prevista nos arts. 578 e seguintes da CLT, é devida por todos os trabalhadores de determinada categoria, inclusive pelos servidores públicos. Precedentes. 3. Recurso especial provido. (SUPERIOR TRIBUNAL DE JUSTIÇA, RESP 442.509/SP, 2 ${ }^{\mathrm{a}}$ turma, Relator João Otávio de Noronha, Publicado no DJ 14/08/2006) 
empregados regidos pela CLT deve ser aplicado aos servidores públicos estatutários, posto que trata de questão, inclusive, já pacificada pelo próprio STF. A analogia, de acordo com o CTN, é vedada no que diz respeito à exigência de tributo como obrigação principal, como é o caso, nos termos do artigo $108, \S 1^{\circ}$.

Inequívoco é que as decisões dos Tribunais Superiores infringem o princípio da legalidade tributária, ao entender que a Administração Pública tem o dever de efetuar o desconto da contribuição sindical dos vencimentos dos servidores públicos estatutários, sem qualquer legislação que autorize tal recolhimento. A legalidade tributária é critério indispensável de toda a tributação, sem o qual não há que se falar em Direito Tributário.

Sobre o princípio da legalidade tributária Gerd W. Rothmann (1992) aponta:

\begin{abstract}
Concluímos, pois, que é exatamente e $\mathrm{m}$ virtude do princípio da legalidade que a relação jurídico-tributária se caracteriza como relação de direito e não de poder, não havendo nenhuma supremacia de um a das partes sobre a outra. Esta igualdade das partes perante a lei se revela e m toda sua plenitude na hipótese do pagamento indevido do tributo, onde as posições de credor e devedor se invertem, cabendo ao contribuinte o direito de pedir a restituição do indébito. (ROTHMANN, 1992, p. 234)
\end{abstract}

Ademais, é a partir do princípio da legalidade tributária que a lei formal irá definir todos os elementos constitutivos da obrigação tributária, ou seja, todas as características do fato gerador daquele tributo. Nesse sentido, Amílcar Falcão (1971, p. 37) entende que “definir, caracterizar, conceituar por lei o fato gerador do tributo é, entretanto, um dos aspectos mais relevantes do chamado princípio da legalidade dos tributos, ou da reserva da lei em matéria tributária."

Lado outro, a Instrução Normativa $n^{\circ}$ 01/2008 além de exigir o pagamento da contribuição sindical obrigatória do servidor público estatutário, indubitavelmente, ela define de forma equivocada o fato gerador da obrigação tributária e, portanto, infringe o princípio da legalidade tributária estrita.

Não é demais ponderar que a obrigação tributária principal se rege pelos princípios específicos da reserva da lei formal e da estrita legalidade tributária. Então, em se tratando da legalidade, os servidores públicos estatutários não podem ser considerados como sujeitos passivos da contribuição sindical prevista nos artigos 578 e seguintes da CLT, conforme prevê o ato normativo do MTE. 
A CLT trata expressamente a obrigação tributária definindo o rol dos contribuintes que estão sujeitos ao pagamento da contribuição sindical, que são os empregados, autônomos e empregadores, não se confundindo com os servidores públicos estatutários.

Destarte, a Instrução Normativa n01/2008 do Ministério do Trabalho e Emprego padece de ilegalidade, posto que, diante da sua matéria tributária, deve estar restrita exclusivamente à disciplina por lei ordinária e não como norma autoaplicável do artigo $8^{\circ}$, inciso IV, parte final da $\mathrm{CF} / 88$, como o STF tem se posicionado a respeito.

\section{CONCLUSÃO}

O sindicalismo brasileiro teve importante contribuição na evolução dos direitos do trabalho coletivo e individual no Brasil, apesar da era de grandes transformações sociais e políticas vivenciadas quando do seu surgimento, a partir de 1930.

Ao longo das Constituições, os sindicatos continuavam vinculados ao Poder Público, sendo que somente com a CF/88 é que foi possível vedar a interferência do Estado nas atividades dos sindicatos (inciso $\mathrm{I}$ do artigo $8^{\circ}$ ) e garantir a liberdade de associação (inciso $\mathrm{XX}$ do artigo $5^{\circ}$ e inciso $\mathrm{V}$ do artigo $8^{\circ}$ ), bem como assegurar novos direitos fundamentais.

Com o intuito de fortalecer o movimento sindical, foi instituída a contribuição sindical obrigatória, cuja origem se deu através da Constituição de 1937, no artigo 138, com a sua posterior regulamentação pelo Decreto-Lei no 2.377 de 1940. Ela restou assegurada nos artigos 578 a 610 da Consolidação das Leis Trabalhistas, tendo sido recepcionada pela CF/88. Importante destacar que a contribuição sindical se mantémcomo uma das principais fontes de custeio das atividades sindicais.

A natureza jurídica tributária da contribuição sindical é questão inquestionável, posto que reúne todas as características de tributo, conforme dispõe o artigo $3^{\circ}$ do CTN.Ademais, é considerada como uma contribuição especial - prevista no artigo 149 da CF/88 - com função para fiscal e finalidade específica, qual seja, custear a atividade sindical. Tal contribuição corresponde ao desconto de 1 (um) dia de trabalho anual nos salários dos trabalhadores, independentemente de serem filiados ou não à qualquer entidade sindical.

É nessa seara, que a contribuição sindical é obrigatória para todos aqueles que se enquadram dentro da exigência do artigo 578 da CLT, independentemente, como dito, de serem filiados ou não à entidade sindical. 
Entretanto, o Ministério do Trabalho e do Emprego editou a Instrução Normativa n01/2008, que estendeu a obrigatoriedade do recolhimento da contribuição sindicalpara os servidores públicos estatutários, a partir de alguns precedentes do STF e do STJ,que, com a devida vênia, não estão em consonância com a matéria.

A contribuição sindical é pautada pelas regras e princípios do Direito Tributário. Desse modo, o princípio da legalidade tributária estrita está assegurado no artigo 150, inciso I da $\mathrm{CF} / 88$, sendo que não poderá haver nenhuma exigência de tributo sem que tenha lei anterior que o defina. É nesse contexto, que a contribuição sindical é obrigatória para aqueles que participem das categorias econômicas ou profissionais ou das profissões liberais (art. 578, CLT), não se enquadrando no caso, os servidores públicos estatutários.

Deste modo, apesar dos julgados majoritários dos Tribunais Superiores entenderem ser devido o pagamento da contribuição sindical obrigatória prevista no artigo $8^{\circ}$, inciso IV, parte final da $\mathrm{CF} / 88$, para os servidores públicos estatutários, ousamos discordar de tal posicionamento, posto que fere amplamente o princípio da legalidade tributária previsto na Carta mandamental. Ademais, ainda, no Direito Tributário, é vedada a aplicação da interpretação por analogia, nos casos de implicação de pagamento de tributo como obrigação principal, em conformidade com o artigo $108, \S 1^{\circ}$ do CTN.

Inadmissível aceitar que o tratamento conferido aos empregados celetistas seja aplicado aos servidores públicos estatutário. Nítida é a diferença entre ambos, uma vez que os servidores públicos estatutários são vinculados à Administração Pública direta ou indireta, no âmbito da União, dos Estados ou Municípios e regidos por lei específica. Lado outro, os empregados regidos pela CLT, possuem contrato de natureza privada e, por vedação legal, inaplicável ao servidor público.

Não obstante, os incisos I e II do artigo 580 da CLT,elucidam, de forma clara e taxativa,os sujeitos passivos da contribuição sindical, que são: empregados, agentes ou trabalhadores autônomos e profissionais liberais.

Portanto, é descabívela exigência do pagamento de tributo, cujo sujeito passivo não tenha obrigação tributária principal, prevista em lei, como é o caso do servidor público estatutário.É através da lei, que serão disciplinados todos os requisitos para a obrigação tributária, inclusive a definição do fato gerador, e não através de um ato normativo.

Desse modo, a Instrução Normativa $\mathrm{n}^{\circ} 01$ de 30 de Setembro de 2008expedida pelo Ministério do Trabalho e do Emprego que estendeu a obrigatoriedade da contribuição sindical 
obrigatória para o servidor público estatutário é ilegal, não encontrando qualquer amparo no ordenamento jurídico brasileiro.

\section{REFERÊNCIAS BIBLIOGRÁFICAS}

ALEXANDRE, Ricardo. Curso de Direito Tributário Esquematizado. $6^{\text {a }}$ ed. São Paulo. Editora: Método, 2012.

BRASIL. Constituição (1988). Constituição da República Federativa do Brasil de 1988. Brasília: Senado Federal, 1988. Disponível em: <http://www.planaltogov.br/ccivil_03/constituicao.html>. Acesso em 16 de mai. 2016.

Ministério do Trabalho e do Emprego. Instrução Normativa no 01, de 30 de Setembro de 2008. Disponível em: http://portal.mte.gov.br/data/files/FF8080812BD96D6A012BE3B0AF2309A5/in_20081003_01.pdf. Acesso em 12 de mai. 2016.

Lei n. 5.172, 25 de outubro de 1966. Dispõe sobre o Sistema Tributário Nacional e institui normas gerais de direito tributário aplicáveis à União, Estados e Municípios.Brasília: Senado Federal, 1966. Disponível em:<http://www.planalto.gov.br/ccivil_03/leis/L5172.htm>. Acesso em 12 de mai. 2016.

Constituição (1934). Constituição da República dos Estados Unidos do Brasil de 1934.Brasília: Senado Federal, $1934 . \quad$ Disponível em: <http://www.planalto.gov.br/ccivil_03/Constituicao/Constituicao34.htm>. Acesso em 12 de mai. 2016.

Constituição (1937). Constituição dos Estados Unidos do Brasil de 1937. Brasília:

Senado Federal, $1937 . \quad$ Disponível em:
<http://www.planalto.gov.br/ccivil_03/Constituicao/Constituicao37.htm>. Acesso em 18 de jun. 2016. Constituição (1946). Constituição dos Estados Unidos do Brasil de 1946. Brasília: Senado Federal, $1937 . \quad$ Disponível em: http://www.planalto.gov.br/ccivil_03/Constituicao/Constituicao46.htm>. Acesso em 12 de maio. 2016. 
. Constituição (1967). Constituição da República Federativa do Brasil de 1967. Brasília:

Senado Federal, $1967 . \quad$ Disponível em: <http://www.planalto.gov.br/ccivil_03/Constituicao/Constituicao67.htm>. Acesso em 12 de mai. 2016.

Decreto n. 19.433, de 26 de novembro de 1930. Cria uma Secretaria de Estado com denominação de Ministério do Trabalho,Indústria e Comércio.Brasília: Câmara Federal, 1930. Disponível em: <http://www2.camara.leg.br/legin/fed/decret/1930-1939/decreto-19433-26-novembro1930-517354-publicacaooriginal-1-pe.html>. Acesso em 18 de jun. 2016.

Decreto n. 19.770, de 19 de março de 1931. Regula a sindicalisação das classes patronaes e operárias e dá outras providências. Brasília: Senado Federal, 1931. Disponível em: < http://www.planalto.gov.br/ccivil_03/decreto/Antigos/D19770.htm>. Acesso em 12 de mai. 2016.

Decreto-Lei n. 1.402, de 05 de julho de 1939. Regula a Associação em Sindicato. Brasília: Senado Federal, 1939. Disponível em: <http://www.planalto.gov.br/ccivil_03/decretolei/Del1402.htm>. Acesso em 12 de mai. 2016.

Decreto-Lei n. 2.377, de 08 de julho de 1940. Dispõe sobre o pagamento e a arrecadação das contribuições devidas aos sindicatos pelos que participam das categorias econômicas ou profissionais representadas pelas referidas entidades. Brasília: Câmara dos Deputados. Disponível em: <http://www2.camara.leg.br/legin/fed/declei/1940-1949/decreto-lei-2377-8-julho-1940-412315publicacaooriginal-1-pe.html>. Acesso em 12 de mai. 2016.

Decreto-Lei n. 4.298, de 14 de maio de 1942. Dispõe sobre o recolhimento a aplicação do imposto sindical e dá outras providências. Brasília: Câmara dos Deputados, 1942. Disponível em: < $\quad$ http://www2.camara.leg.br/legin/fed/declei/1940-1949/decreto-lei-4298-14-maio-1942-414332publicacaooriginal-1-pe.html>. Acesso em 12 de mai. 2016.

Decreto-Lei n. 5.452, de 01 de maio 1943. Aprova a Consolidação das Leis do Trabalho.Brasília: Senado $\quad$ Federal, Disponível em: <http://www.planalto.gov.br/ccivil_03/decreto-lei/Del5452.htm>. Acesso em 12 de mai. 2016. . Lei $\mathrm{n}^{\circ} 4.140$, de 21 de setembro de 1962. Altera as alíneas b e c do artigo 580 do Decreto-lei número 5.452, de $1^{\circ}$ de maio de 1943 (Consolidação das Leis do Trabalho), e dá 
outras providências. Brasília: Senado Federal, 1962. Disponível em: <http://www.planalto.gov.br/ccivil_03/leis/L4140.htm>. Acesso em 12 de mai. 2016.

Decreto-Lei $n^{\circ}$ 27, de 14 de novembro de 1966. Acrescenta à Lei $\mathbf{n}^{\mathbf{0}} \mathbf{5 . 1 7 2}$, de 25 de outubro de 1966, artigo referente às contribuições para fins sociais. Brasília: Senado Federal, 1966. Disponível em: <http://www.planalto.gov.br/ccivil_03/decreto-lei/1965-1988/Del0027.htm>. Acesso em 12 de mai. 2016.

Decreto-Lei nº 229, de 28 de fevereiro de 1967. Altera dispositivos da Consolidação das Leis do Trabalho, aprovada pelo Decreto-lei $n^{0} 5.452$, de $1^{\circ}$ de maio de 1943 , e dá outras providencias. Brasília: Senado Federal, 1967. Disponível em: <http://www.planalto.gov.br/ccivil_03/decreto-lei/Del0229.htm>. Acesso em: 12 de mai. 2016.

Lei $n^{\circ} 5.889$, de 08 de junho de 1973. Estatui normas reguladoras do trabalho rural. Brasília: $\quad$ Senado $\quad$ Federal, $1973 . \quad$ Disponível em: <http://www.planalto.gov.br/ccivil_03/leis/L5889.htm>. Acesso em 12 de mai. 2016.

Supremo Tribunal Federal. Agravo Instrumento n. 456.634, DJ 24.02.06. $2^{\mathrm{a}}$ Turma. Relator Carlos $\quad$ Velloso. $\quad$ Disponível em: http://redir.stf.jus.br/paginadorpub/paginador.jsp?docTP=AC\&docID=315058>. Acesso em 12 de mai. 2016.

Supremo Tribunal Federal. Embargos de Declaração em Rext com Agravo n. 723.891, DJ 24.08.15. $\quad 2^{\mathrm{a}}$ Turma. Relator Gilmar Mendes. Disponível em: < http://redir.stf.jus.br/paginadorpub/paginador.jsp?docTP=TP\&docID=9218541>. Acesso em 12 de mai. 2016

Supremo Tribunal Federal. Recurso Extraordinário n. 180.745, DJ 08.05.1998. 1ª Turma.

Relator Sepúlveda Pertence. Disponível em:
$<$ http://redir.stf.jus.br/paginadorpub/paginador.jsp?docTP=AC\&docID=225529>. Acesso em 12 de mai. 2016

Supremo Tribunal Federal. Recurso Extraordinário n. 146.733, DJ 06.11.92. Tribunal Pleno. $\quad$ Relator: $\quad$ Moreira Alves. Disponível em:<http://redir.stf.jus.br/paginadorpub/paginador.jsp?docTP=AC\&docID=210152>. Acesso em 12 de mai. 2016. 
Superior Tribunal de Justiça. Recurso Especial n. 612.846, DJ 11.04.05.Segunda Turma.

Relator: $\quad$ Eliana Calmon. Disponível em: $<$ https://ww2.stj.jus.br/processo/revista/inteiroteor/?num_registro=200302103422\&dt_publicacao=11/ 04/2005>. Acesso em 12 de mai.2016.

. Superior Tribunal de Justiça. Recurso Especial n. 442.509, DJ 14.08.06.Segunda Turma.

Relator: João Otávio de Noronha. Disponível em: $<$ https://ww2.stj.jus.br/processo/revista/inteiroteor/?num_registro=201303952669\&dt_publicacao=04/ 04/20145>. Acesso em 12 de mai.2016.

CARVALHO, Daniel Pinheiro de. Contribuição Sindical e servidores públicos estatutários. Analise da legislação e da jurisprudência. Teresina, Ano 14, n. 2196, 06 de julho de 2009.

DELGADO, Maurício Godinho. Curso de Direito do Trabalho. 08ª ed. São Paulo: LTr, 2009.

FALCÃO, Amílcar de Araujo. Fato Gerador da obrigação tributária. 2.a ed. São Paulo: 1971.

MACHADO, Hugo de Brito. Curso de Direito Tributário, 16ª ed. São Paulo: Malheiros, 2001.

MARTINS, Sergio Pinto. Contribuições Sindicais: direito comparado e internacional:

Contribuições assistencial, confederativa e sindical.2a Edição. São Paulo. Editora: Atlas, 1998.

NASCIMENTO, Amauri Mascaro. Curso de Direito do Trabalho: historia e teoria geral do direito do trabalho: relações individuais e coletivas do trabalho. $28^{a}$ ed. São Paulo: Saraiva, 2013.

NASCIMENTO, Amauri Mascaro. Compêndio de Direito Sindical. 4a ed. São Paulo. LTr, 2005.

NASCIMENTO, Amauri Mascaro. Direito Sindical. $2^{a}$ ed. São Paulo. Editora: LTr, 1984.

ROTHMANN, Gerd W. O principio da legalidade tributária. Revista da Faculdade de Direito da Universidade de São Paulo, 1992.

ROZICKI, Cristiane. Aspectos da liberdade sindical. $2^{\mathrm{a}}$ ed. São Paulo: LTr, 1988.

SABBAG, Eduardo. Manual de Direito Tributário. $6^{\text {a }}$ ed. São Paulo: Saraiva, 2014.

SAFFRAIDER, Luiz Fernando. Entidades sindicais: teoria e prática. $3^{\mathrm{a}}$ ed. Curitiba: Juruá, 2006. 
SANTOS, Luciana Batista. Direito Tributário. 2ª ed. Belo Horizonte: Del Rey, 2011.

SOUZA Zoraide Amaral de. A Associação Sindical no Sistema das Liberdades. $3^{a}$ ed. São Paulo: LTr, 2008.

VIANNA, Segadas. Organização Sindical Brasileira. $2^{\mathrm{a}}$ ed. Rio de Janeiro: Cruzeiro, 1943. 